\title{
Profitability Analysis of Pigeon Pea (CajanusCajan) Production in Riyom Lga of Plateau State
}

\author{
Emefiene, M.E.
}

Joshua V.I.

Nwadike C.

Yaroson, A.Y.

Zwalnan, N. D. E.

Department of Agricultural Science, Federal College of Education, Pankshin, Plateau State

Doi:10.5901/ajis.2014.v3n7p44

\section{Abstract}

The study focused on the profitability of pigeon pea production in Riyom LGA of Plateau State. Data for the study were obtained from both primary and secondary sources. Questionnaires were administered to 80 targeted farmers to get information on their socio-economic characteristics, years of experience in pigeon pea production and the reason for growing pigeon pea. The analytical tool used includes descriptive statistics to analyze the socio-economic characteristics of the farmers and farm budgeting technique (gross margin analysis) for assessing the profitability of pigeon pea production. The study also identified the constraints encountered by farmers such as high cost of labour, inadequate processing/ storage facilities, problems of access to credit/loans and weed/pest infestation. The results shows that pigeon pea production is profitable with a total variable cost (TVC) at N22620.68 per ha, while gross revenue (GR) was N50185.25 per ha, the profit margin (GM) at N32564.59 and the net return per Naira invested was N0.69. It was recommended that farm inputs and improved seed varieties should be made available to farmers at affordable rates so as to enable them operate at a commercial and profitable level of pigeon pea production. These farmers should be encouraged to form a cooperative society so as to alleviate the problem of credit/ loan acquisition and procurement of genuine products as well as avoid exploitation.

Keywords: Profitability, Pigeonpea production, Constraints, Loan acquisition and Procurement.

\section{Introduction}

The yield of pigeon pea (Cajanus cajan (L.) Millsp.)has remained low on the farmers' fields in Central Guinea Savanna agro-ecological environment of Nigeria, despite its agronomic potentials. In 2002 - 2004, twenty-nine (29) improved pigeon pea genotypes from ICRISAT were evaluated along with a local check for grain yield and other agronomic characteristics with a view to further enhance pigeon pea productivity in the region.

At the turn of the $19^{\text {th }}$ century, long before the advent of the agricultural chemical industry, agriculturists in Hawaii were growing a hardy, drought-tolerant legume from India known as the pigeonpea (Cajanuscajan). First used as a windbreak and for livestock feed, the plant became very popular and eventually was grown on over 10,000 acres, inter planted with pineapple as a "soil builder." Pigeonpea still offers the same excellent array of features, now valued by contemporary farmers who are trying to practice sustainable agriculture. Today, in terms of global production of legume crops, pigeonpea is sixth after Phaseolus species (common beans), peas, chickpeas, broad beans, and lentils

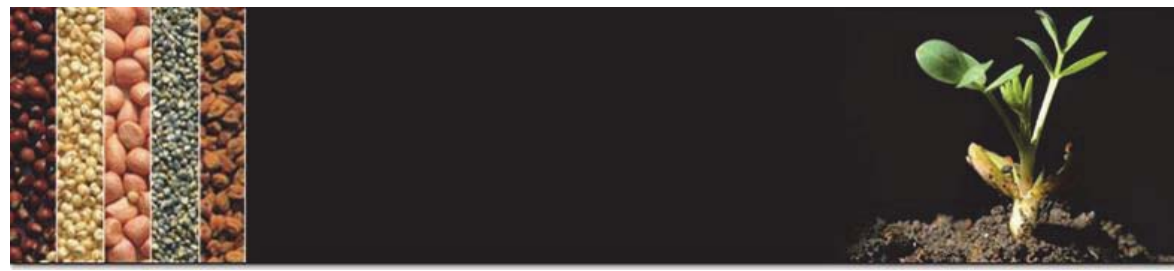

Source:Field Survey, 2014 
The Pigeon pea (cajanuscajan) plant is a legume belonging to the family of "Fabaceae" or "Leguminosae". It is a perennial plant used extensively as a livestock feed and for manufacturing pulses. It originated from Barbados, where this crop is an important pigeon feed. There are several alternative names for this plant. This plant is grown in many regions across the world and is known by different names, such as the Tropical green pea, Red gram and Kadios in Philippines. The pigeon pea plant is extensively cultivated in different parts of India and Eastern Africa. Apart from these two main locations, there are also some other locations where it is grown: Myanmar, Thailand, Ethiopia, Kenya, Tanzania, Nigeria, Mozambique, Malawi, Australia, Florida, Jamaica, Central America.
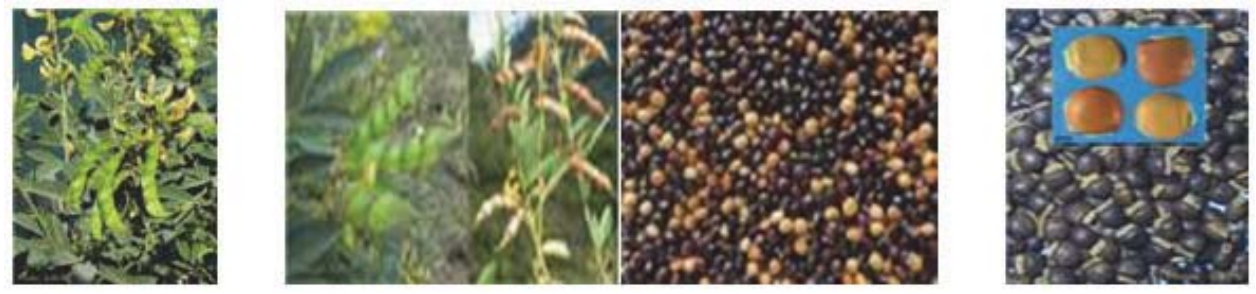

Source: Field Source Survey, 2014

The crop is locally available in Nigeria, affordable and underutilized grain legume of the tropics and sub tropics. It has protein content in the range of $23-26 \%$ (Oshodi et al, 1985). The protein content is comparable with those in other legumes like cowpea and groundnut which has been used in complementing maize diet. It is rich in mineral quality and fiber content. It grows well in Nigeria (Edo Enugu, Benue) but the hard- to- cook phenomenon and the presence of antinutrients have limited its utilization (Nene et al, 1984; Eltabey, 1992).

Pigeonpea is an erect perennial legume shrub often grown as an annual, reaching 3-12 ft (1-4 meters) in height. The leaves have three leaflets that are green and pubescent above and silvery grayish-green with longer hairs on the underside. The flowers are yellow with red to reddish-brown lines or a red outside. Pigeonpea seed lings emerge 2-3 weeks after sowing. Vegetative growth begins slowly but accelerates at 2-3 months. Pigeonpea roots are thin with a deep-rooting taproot reaching up to $6 \mathrm{ft}(2 \mathrm{~m})$ in depth. This deep rooting system helps to improve water infiltration into the soil. Research in India showed greater water infiltration in a sorghum-pigeonpea rotation than in sorghum monocultures

Pigeon pea is a perennial legume shrub that lives around one to five years. It is grown annually, reaching a height of around 1-4 meters. Pigeon pea plants are woody near the base. The leaves are comprised of three leaflets. They are pubescent and green on the upper side and silvery grayish-green having long hairs on the lower side. The leaflets can be either elliptic or lanceolate in shape. They are normally $2.5 \mathrm{~cm}$ to $10 \mathrm{~cm}$ long and almost $3.5 \mathrm{~cm}$ wide. The flower blossoms are yellow in color having red or reddish-brown lines. Sometimes the flowers may have a red lining on the outer edge. They are grown in terminal racemes. The flowers have a diameter ranging between $1.2 \mathrm{~cm}$ and $1.7 \mathrm{~cm}$. The seeds vary greatly in their color. They may be white, cream-yellow, brown or almost black. The seeds can be squarish, globose or ellipsoid. Pigeon pea has taproots which are tetrarch, thin and grows deep under the ground, reaching to a depth of six feet. The deep roots help in improving infiltration of water into the soil.

\section{Vernacular Names}

Pigeon pea, Congo pea, red gram (En). Pois cajan, pois d'Angole, ambrevade (Fr). Ervilha do Congo, feijão guandu, ervilha de Angola (Po). Mbaazi (Sw).

\section{Objectives of the Study}

1. To examine the socio-economic status of the respondents.

2. To examine the profitability of pigeona production in the study area.

3. To examine the challenges militating against pigeonpea production in the study area.

4. To estimate the cost and returns of Pigeonpea (cajanus cajan ) production, productivity of use of farm resources and seasonal price pattern. 


\section{Conceptual Framework}

Pigeonpea significantly contributes to meet the dietary requirements of crude fiber, ash, fat,magnesium, manganese, and copper (Faris and Singh1990). Pigeonpea contains high amounts of vitamin B, carotene, and ascorbic acid (Miller etal.1956). These are deficient in cereals; therefore, pigeonpea has a good supplemental value of cereal-based diet. Pigeonpea is a rich source of lysine but deficient in the sulfur-containing amino acids-methionine and cystein. Cereal grains contain sufficient levels of methionine and cystein. Faris and Singh (1990) reported that pigeonpea improves the amino acid score for lysine in rice- and wheat-based diets, and for threonine, leucine, and isoleucine in wheat-based diet when used in a 70:30 cereal :pigeonpea ratio.

\subsection{Chemical and nutritional value}

Cajan pea (Cajanus cajan), aerial part, fresh; Cajan pea (Cajanus cajan), hay; Cajan pea; (Cajanus cajan), leaves, dry; Cajan pea (Cajanus cajan), pod husks; Cajan pea (Cajanus cajan), pods; Cajan pea (Cajanus cajan), seeds; Cajan pea (Cajanus cajan), seeds, cracked; Cajan pea (Cajanus cajan), seeds, dried; Cajan pea (Cajanus cajan), seeds, fresh. Rich in calcium, magnesium, potassium and phosphorus, Pigeon pea contains fewer amounts of copper, zinc and magnesium and good amount of selenium and iron.

\subsection{Cultivars}

The pigeonpea cultivars commonly recommended for use as green manure by the Hawaii NRCS are 'Norman' and 'FL81d'. These cultivars are shorter and shrubbier and resistant to root-knot nematodes (Meloidogyne incognita).

\subsection{Establishment}

Inoculate seeds with a cowpea-type rhizobium inoculant. Broadcast 40-60 lb/acre pure live seed. Use the higher rate if severe weed competition is expected or if the crop is to be incorporated as a green manure after a short period of growth; a denser stand produces finer stemmed, more succulent material that is easier to work into the soil. Broadcast and cover or drill to a depth of 1-4 inches $(2.5-10 \mathrm{~cm})$.

\section{Uses}

\subsection{Soil improvement}

When used as a green manure, pigeonpea produces about $21 / 2$ tons/acre dry matter and about $50 \mathrm{lb}$ of nitrogen per ton of dry matter, according to NRCS. Fresh weight yields of the top growth can reach up to 35 tons/acre, including about 700 $\mathrm{lb} / \mathrm{acre}$ of seed, making it one of the highest yielding food legumes. Total $\mathrm{N}$ available from a summer pigeonpea planting in Florida was estimated at $250 \mathrm{lb} / \mathrm{acre}$, although only a fraction of this amount became available for the following crop, indicating that the $\mathrm{N}$ is released over a long period of time.

When planted at a CTAHR's low elevation Waimanalo Research Station on Oahu in mid-September, foliage fresh weight was about 15,000 lb/acre after about 14 weeks of growth. A summer planting (mid-June) at the same site resulted in foliage fresh weight ranging from 43,000-80,000 lb/acre when flail-mowed 23 weeks after planting. Plants in the 14week fall planting grew to about $5 \mathrm{ft}$ tall, and in the summer planting they grew to 8-10 ft. The tissue nitrogen content of pigeonpea foliage is about $21 / 2 \%$.

Farmers profit from the natural ability of legumes to fix nitrogen. As for all legumes, to optimize nitrogen fixation be sure the soil has a sufficiency of micronutrients (iron, sulfur, molybdenum), suitable $\mathrm{pH}$, and good aeration (no compaction or waterlogging). When used as a green manure, pigeonpea should produce quick improvements in the topsoil. Its extensive root system makes soil more friable, improves its tilth, and facilitates water infiltration. Pigeonpea is also known for its ability to access insoluble phosphates in soils low in $\mathrm{P}$, increasing the availability of soluble $\mathrm{P}$ for the following cash crops in the rotation. Research in India showed that the roots of pigeonpeas release piscidic acid, which reacts with iron-bound phosphate in the soil to release $P$. 


\subsection{Agroforestry}

Taller pigeonpea varieties can be used as a semi-permanent, perennial component of alley cropping systems. This multifunctional plant can serve as a windbreak and living fence that also produces food and fodder. The leaf litter contributes a mulch that decomposes to add to the soil organic matter, possibly contributing as much as $35 \mathrm{lb} / \mathrm{ac}(40 \mathrm{~kg} / \mathrm{ha})$ of nitrogen to the soil. Pigeonpea can-not tolerate the frequent, severe cutting or heavy defoliation pressure typical of continuous grazing operations

\subsection{Ruminants}

Pods, seeds and leaves are excellent fodder for cattle, which can be folded on the unharvested crop. Widely used for hay and silage (often with molasses), especially the small-seeded varieties. If cut for hay when the pods are well developed, it should be cut successively higher. Grazing may damage the plants.

In a comparison of several legume seeds in the Southern Great Plains of the USA, the protein and in vitro digestible DM of cajan peas indicated that they could be efficient replacements for maize or cottonseed meal in livestock diets, assuming that cajan pea could generate enough grain biomass to be cost-effective. Though not as effective as soybean, cajan pea was capable of accumulating useful levels of protein and digestible dry matter under the variable growing conditions of the study (Rao et al., 2009).

\subsection{Poultry}

The nutritional profile of pigeon pea is interesting for poultry, with values close to field pea widely used in animal feeding. Antinutritional factors are present but in a lesser quantity than for other legume seeds, leading to higher nutritive value (e.g. Nwokolo et al., 1985; Ologhobo, 1992). In particular the toxicity assessed by the effect of pigeon pea on organ weights or blood parameters is generally low (Ologhobo, 1992). However a high variability in nutritional value is reported in literature, with sometimes low digestibility values (Chrysostome et al., 1998; Nwokolo, 1987; Yamazaki et al., 1988). This can be due to:

- Variation in composition and ANFs. For examples white-seeded varieties are sometimes claimed to have a higher nutritional value than dark ones (Odeny, 2007) even if in some cases experiments fail to confirm this finding (Nwokolo et al., 1985).

- Formulation of diets. In some cases the level of amino acids (particularly methionine) is deficient in experimental diets, which can lead to mis-interpretation of results (Babiker et al., 2006)

- Technological treatements. Thermal treatements seem to have a positive effect on protein digestibility and energy value (Chrysostome et al., 1998; Onu et al., 2006).

\subsection{Broilers}

Although the results are not always constant through experiments, the general finding is that pigeon pea can lower performance (Oso et al., 2012; Onu et al., 2006). High incorporation rates above 20\% degrade performance (Amaefule et al., 2011; Ani et al., 2011; Etuk et al., 2003). In some cases the degradation can occur at low incorporation rates such as 5 to 10\% (Babiker et al., 2006; Saeed et al., 2007, Oso et al., 2012). The effect seems to be higher in starters than in finisher broilers (Igene et al., 2012; Ani et al., 2011). Feed intake is often unaffected or even increased, which suggests that pigeon pea does not induce palatability problems (Tangtaweewipat et al., 1989). However in this case feed efficiency is degraded. In some cases, growth performance were maintained with 10 to 20\% raw pigeon pea (Ologhobo, 1992; de Oliveira et al., 2000; Tangtaweewipat et al., 1989; lorgyer et al., 2009).

Many trials tried to improve performance with technological treatments as thermal treatments (roasting or cooking), soaking, fermentation or dehulling (e.g. Onu et al., 2006; Abdelati et al., 2009). In most cases the growth performance of broilers is improved, with no clear advantage to one particular processing except that fermented pigeon pea did not allow good animal performance (Oso et al., 2012). Optimization of thermal treatments showed that over-processing (e.g. autoclaving at $120^{\circ} \mathrm{C}, 30 \mathrm{mn}$ ) led to decreased performance (Pezzato et al., 1995). Toasted pigeon pea could support growth up to 27\% in finishers while performance was degraded (although NS) in younger birds (Ani et al., 2011).

An important point is amino acid balance, since several authors improved performance with methionine (but no lysine) addition (Amaefule et al., 2011; Babiker et al., 2006). This could be linked to the deficiency of PP in sulfur amino 
acids (Met and Cys) and the low digestibility of protein in raw pigeon pea. Amino acid deficiency could also explain increased feed intake in some contexts.

In summary, the general recommendation in broilers would be to limit incorporation to $10 \%$ pigeon pea in young animals. With processed (e.g. toasted) pigeon pea and in older animals, higher incorporation rates as 20\% could be used. In less intensive conditions, higher rates could be tested if pigeon pea is available at low cost. However feed efficiency can be lowered. In any case, a particular attention should be paid to amino acid supply, particularly methionine.

\subsection{Layers}

Using pigeon pea often leads to reduced performance in laying hens. Hen-day egg production tends to decrease with raw pigeon pea (Amaefule et al., 2007; Agwunobi, 2000; Tangtaweewipat et al., 1989) although in some experiments production is maintained with $20 \%$ pigeon pea (Udedibie et al., 1989). Feed intake increases, which leads to a degradation of feed efficiency (Amaefule et al., 2006; Amaefule et al., 2007). Delayed start of lay has been recorded (Amaefule et al., 2006; Amaefule et al., 2007). Technological treatments as toasting or boiling can improve performance (Amaefule et al., 2006; Amaefule et al., 2007). Pigeon pea leaf meal was also tested in layers. It allowed maintaining laying performance up to $7.5 \%$ but feed efficiency decreased due to an increase in feed intake (Udedibie et al., 1989). Egg yolk color score was increased by pigeon pea leaf meal in diet. *337f Pigeon pea can be used in pullets (Amaefule et al., 2004; Amaefule et al., 2006). Technological treatments improve the efficiency of use of pigeon pea (Amaefule et al., 2006). The recommendations are the same as in broiler finishers. The overall recommendation in layers is to use pigeon pea with care to avoid a degradation of feed efficiency. It should be safe to use $10 \%$ pigeon pea in diets, with a special care on methionine content in the diet. Higher rates (20\%) can be tested especially if a technological treatment can be applied to pigeon pea.

\subsection{Quails}

In quails toasted pigeon pea allowed good growth performance even at 20-30\% in diets (Yisa et al., 2013). However increase feed consumption led to a degradation of feed efficiency.

\subsection{Crustaceans}

Husks: Husks of Cajanus cajan offer excellent alternatives to rice bran as a diet source for Artemia sp. in terms of survival, growth, fecundity, and naupliar production (Yoganandhan et al., 2000).

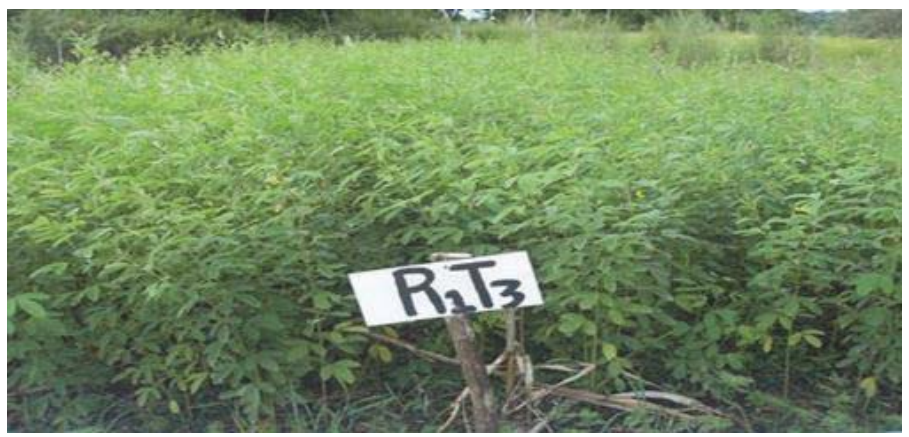

Source:Field Survey, 2014

Pigeon pea used as cover crop

\subsection{Intercropping}

Due to its deep root system, pigeonpea offers less competition to associated crops than some other legumes,and it is often used in intercropping systems with cereals such as millet, sorghum, and maize or with short-duration legumes such as cowpea. Its initial growth isslow, and thus as an intercrop it is initially less competitive for light, water, and soil nutrients when grown as acompanion with short-season cash crops. Animals allowed to graze intercropped fields after the main cropsare removed eagerly browse on pigeonpea. 


\subsection{Food}

Pigeonpea is widely known for its use as food. Immature pods, immature seeds, and the mature seeds can be consumed. The seeds are used whole, dehulled, or ground to a flour. In the Caribbean, people often eat the seed as the green (immature) pea, but it is mostly processed into a dried split-pea ("dahl").

\subsection{Feed}

Pigeonpea foliage is an excellent fodder with high nutritional value. The plants can be grazed, but this should be carefully managed as the plant stems are brittle and easily broken. Pigeonpea should be allowed to develop well before being grazed, and the plants cannot tolerate continuous grazing.

\subsection{Wood}

Pigeonpea is an important source of household fuelwood for subsistence farmers. Its productivity makes up for the relatively poor fuel characteristics of the wood. The woody stems are also used as thatch and for temporary fencing.

\subsection{The health benefits}

A fine paste made of pigeon pea when applied regularly helps treating bald patches. Juice prepared from its leaves with a pinch of salt is said to an effective remedy in jaundice treatment. Swelling could be reduced by poultice made from seeds. Inflammation of internal organs and swelling are not much of a problem with pigeon pea to the rescue. When mixed with water, it is known to ease intoxicating effects.

\section{Pest management}

Once the crop is well established, pigeonpea can smother weed growth in the field and help maintain the field weed-free for the following crop in the rotation. Some pigeonpea varieties are reportedly resistant to the root-knot nematode. Also, studies have shown that pigeonpea roots inoculated with beneficial mycorrhizal fungi not only improve the availability of nutrients to the plant but also the plant's tolerance of nematodes and diseases; these fungi are often naturally available in the soil.

\subsection{Management cautions}

The seedling is fairly slow to establish, and weed control for the first two months of growth considerably improves its development. Once established, it grows vigorously. Cut pigeonpea at flowering or mid-flowering to obtain maximum legume $\mathrm{N}$ when using it as a green manure. Select cultivars that are resistant to nematodes. Root growth varies depending on variety, a consideration when growing a cover crop to break hard pans or to improve water infiltration. The roots of "early," short-duration types will grow only about $11 / 2 \mathrm{ft}(50 \mathrm{~cm})$ deep into the soil, while the roots of long-duration types may grow up to $6 \mathrm{ft}(2 \mathrm{~m})$ deep.

\subsection{Pest problems}

When managed as a green manure crop, pigeonpea generally has few insect pests. However, if allowed to form pods, pigeonpea may attract pod borers and agromyza fruitflies. In Hawaii, reports indiate that pigeonpea is attacked by the scale insect Coccus elongates, a stem borer, a pod borer (Lycaena boetica) and leaf-eating caterpillars. Pigeonpea can be a host to root-knot and reniform nematodes, but this varies among cultivars.

\section{Cultivation}

Today, pigeon peas are widely cultivated in all tropical and semitropical regions of both the Old and the New Worlds. Pigeon peas can be of a perennial variety, in which the crop can last three to five years (although the seed yield drops considerably after the first two years), or an annual variety more suitable for seed production. Pigeon pea is a perennial 
which can grow into a small tree.

Pigeon peas are very drought resistant, so can be grown in areas with less than $650 \mathrm{~mm}$ annual rainfall. World production of pigeon peas is estimated at $46,000 \mathrm{~km} 2$. About $82 \%$ of this is grown in India. These days it is the most essential ingredient of animal feed used in West Africa, most especially in Nigeria, where it is also grown; in industry, chemicals for medicine as well as other services that are vital for the success of agriculture, such as pollination. The last century has seen the greatest loss of biodiversity through habitat destruction, for instance through conversion of diverse ecosystems to agriculture. Other factors such as the growing threat from introduction of invasive alien species, fostered by globalization of trade and transport, have further exacerbated the situation. On small islands, introduction of invasive alien species, many through agriculture-related activities, is the main threat to biodiversity. In freshwater systems, an estimated 20\% of fish species have become extinct (Wood et al., 2000). Globally, the cost of damage caused by invasive species is estimated to run to hundreds of billions of dollars per year (Pimentel et al., 2001). In developing countries, where agriculture, forestry and fishing account for a high proportion of GDP, the negative impact of invasive species is particularly acute.

\section{Biodiversity}

While agriculture is based on the domestication and use of crop and livestock species, the continuum between (wild) biodiversity and agro biodiversity has been recognized both in research on plant genetic resources and in conservation efforts for many decades-starting with the hypothesis of "centers of diversity" of crop species proposed by in the 1920s. More recently an emphasis on the provisioning services of biodiversity has been added: "Biodiversity, including the number, abundance, and composition of genotypes, populations, species, functional types, communities, and landscape units, strongly influences the provision of ecosystem services and therefore human well-being. Processes frequently affected by changes in biodiversity include pollination, seed dispersal, climate regulation, carbon sequestration, agricultural pest and disease control, and human health regulation. Also, by affecting ecosystem processes such as primary production, nutrient and water cycling, and soil formation and retention, biodiversity indirectly supports the production of food, fiber, potable water, shelter, and medicines" (MA, 2005).

Agro biodiversity is the very stuff of food production and an essential resource for plant and animal breeding. Yet it is a resource that is being lost in situ: in farms and agro ecosystems (FAO, 1996; Thrupp, 1998; CBD, 2006). Its conservation is somewhat framed by a paradox: new breeds have boosted agricultural productivity, but simultaneously they displaced traditional cultivars. In response, gene or seed banks have been created to fulfill a double function: to resource plant breeders with the agro biodiversity needed for further crop development, and to conserve crop diversity that may have disappeared from agricultural systems.

Exsitu conservation in seed repositories and gene banks has long been considered to be the central pillar of agro biodiversity conservation. To be effective, agro biodiversity management needs to operate at several levels: local, national, and international. Against the overall trend of declining diversity in agricultural properties after degradation has occurred.

Soil, just like water, is a key resource for agricultural production. Sometimes erroneously subsumed under "land" issues, the availability of soils for growing crops often seem to be taken for granted. Yet in both the developing and the industrialized world, the loss of productive agricultural soils to urban development is enormous. In addition, according to an estimate by the Global Assessment of Human-induced Soil Degradation (GLASOD), degradation had affected 38\% of the world's cropland, to some extent as a result of human activity (Oldeman et al., 1991). However, GLASOD did not estimate productivity losses associated with land degradation. In the absence of data on the productivity impacts of land degradation, estimates based on different methods vary widely (Wiebe, 2003).

The impact of nitrates from fertilizers and livestock production on soil and water resources is a related issue. This impact can be described in general terms as the nitrification of the global ecosystem from inorganic fertilizers and alteration of the global nitrogen cycle.

\section{Constraints}

Eutrophication as a consequence of nutrient runoff from agriculture poses problems both for human health and the environment. Impacts of eutrophication have been easily discernible in some areas such as the Mediterranean Sea and northwestern Gulf of Mexico (Wood et al., 2000).

Some agricultural activities have led to a reduction of system productivity. For instance, irrigated agriculture has 
contributed to water logging and salinization, as well as depletion and chemical contamination of surface and groundwater supplies (Revenga et al., 2000; Wood et al., 2000; CA, 2007). Manure from intensive livestock production has exacerbated the problem of water contamination

Most of the farmers acquired their land through inheritance. Some of them could not estimate the size of their farm, therefore, the land had to be estimated during the study.

Some farmers use only family labour, hence, cost of operation had to be estimated according to field survey.

Those farmers who went through no formal education were interviewed orally and their responses translated respectively.

\section{Research Methodology}

This study was carries out in Riyom Local Government Area of Plateau State. Riyom LGA shares borders in the south with Nimbia in Jama's LGA of Kaduna State, in the east with Gashish district in Barkin Ladi LGA. Riyom is situated between longitude 8030 'E andlatitude $9000^{\prime} \mathrm{N}$. The vegetation is of guinea savanna wood land typified by deciduous flora and tall herbaceous species. The south east sector has thick forested areas particularly along the river course at about its boundary with Kut village.Primary and secondary data sources including personal or oral interview, questionnaire, information from reconnaissance survey and relevant documents were sourced and used during the study. Data collected were analyzed using descriptive statistics.

\section{Results and Discussion}

The results (Table1) show that the age distribution of respondents between 40 and 45 constitutes the highest pigeon pea farmers in the study area with $40 \%$. The next age group with high percentage representation is $30-35$ by $26.67 \%$ of the respondents, while 50 and above constitutes the lowest population of farmers who engage in pigeonpea production. This indicates that the larger population within the study area is still within the working population.

The sex distribution of respondents reveals that the males have the highest percentage of $66.67 \%$ involved in pigeonpea production. The female folks have $33.33 \%$.thus indicating that women participate less in pigeonpea production.

The educational qualification of respondent shows that $73.33 \%$ of the farmers acquired tertiary education while 13.33 had primary education. It implies that the larger population in the study area acquired the basic education that will enable them adopt new agricultural innovation to aid greater production.

The part-time farmers participated mostly in pigeonpea production which implies that many of the farmers have other jobs or enterprise to support their farming programmes. This means that they know farming strategies and believe that it will help in obtaining greater output.

$50 \%$ of the population has $12-20$ years of farming experience. Farmers with 3-6 years of experience have the lowest population of $6.67 \%$

Table 1: Demographic Status of Respondents

$\begin{array}{lcc}\text { Socio-economic variables } & \text { Frequency (F) } & \text { Percentage (\%) } \\ \text { Age in years } & & \\ 25 \text { and above } & 14 & 23.33 \\ 30-39 & 16 & 26.67 \\ 40-49 & 24 & 40 \\ 50 \text { and above } & 6 & 10 \\ \text { Total } & 60 & 100 \\ \text { Sex } & & \\ \text { Male } & 40 & 66.67 \\ \text { Female } & 20 & 33.33 \\ \text { Total } & 60 & 100 \\ \text { Educational Status } & & \\ \text { Non-formal Education } & 4 & 16.67 \\ \text { Primary } & 8 & 13.33 \\ \text { Secondary } & 4 & 16.67 \\ \text { Tertiary } & 44 & 53.33 \\ \text { Total } & 60 & 100 \\ & & \\ & 0 & \end{array}$




$\begin{array}{lcc}\text { Occupation } & & \\ \text { Full-time } & 16 & 26.67 \\ \text { Part-time } & 44 & 73.33 \\ \text { Total } & 60 & 100 \\ \text { Socio-economic variables } & \text { Frequency (F) } & \text { Percentage (\%) } \\ \text { Years of Experience } & & \\ 1-3 & 6 & 10 \\ 3-6 & 4 & 6.67 \\ 6-12 & 20 & 33.33 \\ 12-20 & 30 & 55 \\ \text { Total } & 60 & 100 \\ \text { Farm Size } & & \\ 0.5-1.0 & 10 & 16.67 \\ 1.1-1.5 & - & - \\ 2.0-2.5 & 18 & 30 \\ 3.0 \text { and above } & 32 & 53.33 \\ \text { Total } & 60 & 100 \\ \text { Household size } & & \\ 1-5 & 20 & 33.33 \\ \text { 6-12 } & 28 & 46.67 \\ \text { 13-17 } & 10 & 16.67 \\ 17 \text { and above } & 2 & 3.33 \\ \text { Total } & 60 & 100 \\ \text { Labour } & & \\ \text { Hired } & 14 & 23.33 \\ \text { Family } & 20 & 33.34 \\ \text { Both } & 26 & 43.33 \\ \text { Total } & 60 & 100 \\ & & \end{array}$

Source: Field Survey, 2014.

Table 2: Gross Margin of Fonio Production

Varible
Land hiring and Preparation
Seed
Fertilizer
Labour
Transportation
Harvesting
Storage /Processing
Total Variable Cost (TVC)
Gross Margin (GM)
Net returns per N invested

Cost N(ha)

4493.80

1444.40

840

2436.96

322

2556.70

5526.80

22620.68

32564.59

0.69

Source: Field Survey, 2014

Table 3: Distribution of Respondents Based on Constraints

Constraints
Fertilizer
Storage/processing facility
Capital
Land
Labour
Road
Pest /weed
Natural disaster
Total

Frequency $(F)$

10

6

18

4

2

4

28

6

60

Source: Field Survey, 2013. 
Farmers whose pigeonpea farm ranges between 3.0 and above were the majority represented by $53.33 \%$ followed by the respondents with farm pigeon pea between 2.0 and 2.5 with $30 \%$.

26 respondents with $43.33 \%$ in the study area make use of both hired and family labour. In line with (Anyanwuocha, 1993) that labour provides the necessary manpower or personnel required for production. Without the human effort provided by labour, land and capital would remain idle. Human effort is required to till the ground for crop farming. Finders, 2000, also revealed that hired labour may be employed year round on a seasonal basis. In either case both family and hired labour are allocated to farming activities.

Table 2 depicts the gross margin analysis of pigeonpea. It reveals that storage and processing constitutes the highest proportion of the total cost of production at N5526.80 per ha, followed by land acquisition and preparation at N4493.80 per ha, transportation constitutes the lowest proportion of the total cost of production at N322 per ha. The gross margin analysis indicates that production is profitable with a gross revenue of N45185.23 per ha and the farmer's profit margin was N27564.57. A naira invested gave a return of N0.69; the average selling price per 50kg ha was N7583.

The total variable cost $(\mathrm{TVC})=\mathrm{N} 22620.68$

Gross revenue $(\mathrm{GR})=$ N50185.25

Gross margin $(\mathrm{GM})=$ GR-TVC $(50185.25-22620.68)=27564.57$

Ten respondents did not use fertilizer which is in line with traditional production practices, while 6 complained of storage facilities and natural disaster respectively.

\section{Recommendation}

It is believed that the following recommendations if properly implemented could enhance agricultural productivity in Nigeria:

- Processing and storage facilities should be provided by the ADPs in order to prolong the shelf life of pigeonpea to earn more profit.

- Processing facilities should be provided by the ADPs in order to eliminate the difficulty encountered during threshing and pounding of the grain.

- Credit /soft loans should be provided to the farmers either through banks or other associations in the community in order to enable them carry out their farming activities efficiently.

- Communities and families should be encouraged to make land available for agricultural purposes.

- The agricultural credit bank should be re-capitalized and made more accessible to small scale farmers.

- Federal and states Ministry of Agriculture should procure more farm equipments and implements which small scale farmers can hire at subsidized rate.

- Farmer settlements should be reintroduced. The farmer should be equipped with modern amenities such as schools, hospitals, pipe borne water and motor able roads.

\section{Conclusion}

The demographic status of the respondents revealed that the age of the farmers in the study area is within the working population and the respondents are educationally qualified to enable them adopt new agricultural innovations and the male gender participates mostly in the production and are experienced for agricultural production. Majority of the farmers cultivate between 3-8 hectares and employ both family and hired labour.

The gross margin of pigeonpea shows that storage and processing constitutes the highest proportion of the total cost of production at N5526.80 per ha, land acquisition and preparation at 4493.80 per ha and transportation at N322 per ha. The farmers profit margin was N27564.57 per ha.

The constraints encountered include high cost of labour, inadequate processing and storage facilitied, weed/pest infestation and lack of crdit/ sloans from banks and other financial institutions. It is hoped that the above mentioned issues and challenges facing the grass root farmer are addressed, would go long way to enhance agricultural productivity in Nigeria and in turn boost food security.

\section{References}

Cajan pea (Cajanus cajan) Feedipedia - Animal Feed Resources Information System - INRA CIRA AFZand FAO 2012-2013 http://www.feedipedia.org/node/329 Last accessed on August 11, 2013. 
Faris, D.G., and Singh, U. (1990). Pigeonpea: nutrition and products. Pages 401-434 in The Pigeonpea(Nene, Y.L.,Hall, S.D., and Sheila, V.K., eds.).Wallingford, Oxon, UK: CAB International.

Folu M. Dania Ogbe and J.F. Bamidele , 2007. Potential of Pigeon Pea (Cajanus cajan) for PlantedFallow in Edo State, Nigeria. Asian Journal of Plant Sciences, 6: Pp. 490-495.

Miller, C. D., Branthoover, B., Seklguchi, N., Deming, H., and Bauer, A. (1956).Vitamin value of foods used in Hawaii.Hawaii Agriculture Experiment Station Technical Bulletin 30: Pp.303-313.

Mulualem T.; Kassa, R.; Varma Penmetsa.; Noelia Carrasquilla-Garcia.; Birinchi K. Sarma.; Subhojit

Datta.; Hari D. Upadhyaya.; Rajeev K. Varshney.; Eric J. B. von Wettberg.; Douglas R. (2012).Genetic Patterns of Domestication in Pigeonpea (Cajanus cajan (L.) Millsp.)and Wild Cajanus RelativesDOI:10.1371/journal.pone.0039563.

Ologhobo, A. D., 1992. Nutritive values of some tropical (West African) legumes for poultry. J. Appl.Poult. Res., 2 (2): $93-104$. www.feedipedia.org/node/14683.Pigeon Peas - Only Foods () www.onlyfoods.net/pigeon-peas.htm.

Rao, R. Vales, M I and Ranga Rao, G V and Sudini, H and Patil, S B and Murdock, L L ... B and Reddy,K K and Bharath, B S and Rao, V R and Murthy, K V S and Wani, S P ICRISAT - OAR...oar.icrisat.org/view/icrisatcreators/Ranga_Rao=3AG_V=3A=3A.htm.

Saxena, K.B. and Kumar, R.V.(2010). Insect-aided natural out-crossing in four wild relatives ofpigeonpea Euphytica Vol. 173.Pp. 329335.

Upadhyaya, H.D.; Reddy, K.N.; Shivali, S.; Varshney, R.K ; Bhattacharjee, P. (2011). Pigeonpeacomposite collection for enhanced utilization of germplasm in crop improvement programs Plant GenetResou Charact Utiliz Vol. . Pp., 97-108.

Yang; G Ash; J Harper; J Varling; P Wenzl.(2006) Low level of genetic diversity in cultivated pigeonpea Comp 113, 585-595. 